\title{
O contemporâneo é uma praça de guerra
}

\author{
Ricardo Barberena \\ Pontifícia Universidade Católica do Rio Grande do Sul. Porto Alegre, Rio Grande do Sul, Brasil.
}

$\mathrm{C}$ erta vez, num curso ministrado no DELFOS/PUCRS, João Gilberto Noll afirmou: "O Contemporâneo é uma praça de guerra". Teorizar sobre a literatura contemporânea é correr o risco de terminar uma discussão aos tabefes. Virginia Woolf já havia advertido sobre o perigo desse tipo de literatura, pois adentramos num campo minado no qual "dois críticos em uma mesa, no mesmo momento, irão pronunciar opiniões completamente diferentes sobre o mesmo livro" (WOOLF, 2007, p. 104). Sem poder conjugar os tradicionais juízos de valor em obras canonizadas, a crítica literária, alijada de uma prática coercitiva e consensual, acaba por se arriscar no tocante à provisoriedade das suas leituras. Não será de se espantar que os críticos "inevitavelmente cheguem aos tapas" (WOOLF, 2007, p. 104). Ao aceitarmos a navegação pelo contemporâneo, assumimos o risco de um constante saber-em-processo que não raramente entra em rota de colisão e conflito, porque um mesmo livro pode ser entendido tanto como uma duradora contribuição à literatura quanto uma mera miscelânea de mediocridade pretensiosa. Uma série de perguntas começa a atormentar esse flanco crítico: Quando começa o contemporâneo? Qual é a característica estética dominante da literatura brasileira contemporânea? Para rascunhar uma tentativa de resposta parcial, é preciso refletir sobre uma ética contemporânea. Segundo Agamben, é possível definir como contemporâneo apenas quem não se deixa cegar pelas luzes do século e consegue entrever nessas a parte da sombra. Ao transitar por essa perversa obscuridade, o passageiro contemporâneo é aquele que percebe o escuro do seu tempo como algo que lhe concerne e não cessa de interpelá-lo, pois "contemporâneo é aquele que recebe em pleno rosto o facho de trevas que provém do seu tempo" (AGAMBEN, 2009, p.60). Pensado nesses termos, o contemporâneo não é mais declinado sob a égide da arbitrariedade sincrônica que pode ser orquestrada conforme as demandas epistêmicas e discursivas. Ou seja: o contemporâneo ora inicia no pós-segunda guerra mundial, ora começa na virada do século XXI, ora inaugura-se após o medievalismo. Nessa oscilante promiscuidade temporal, a contemporaneidade se transforma numa substância disforme que se encaixa nas infinitas caixas de aço de um poder/saber ficcionalizado nos múltiplos enredos de conhecimento. No entanto, se partirmos de uma neurofisiologia da contemporaneidade, não estaremos preocupados com retalhamentos temporais e periodizações fundacionais, mas, sim, com a potencialidade de um mirar-através-do-sombrio da margem, do remoto, do subalterno, do ex-cêntrico. Por isso os contemporâneos "são raros" (AGAMBEN, 2009, p. 59). Ser contemporâneo é, antes de tudo, uma "questão de coragem" (AGAMBEN, 2009, p. 59) porque significa ser capaz não apenas de manter fixo o olhar no escuro da época, mas também de perceber nesse escuro uma luz que, dirigida para nós, distancia-se infinitamente de nós. Confrontada essa leitura do contemporâneo enquanto ethos em relação à tradicional concepção temporal, já bastante questionada pelo seu caráter anárquico e obtuso, instaura-se uma problematização central: De quem sou contemporâneo? Para Roland Barthes, numa anotação incidental, "o contemporâneo é o intempestivo" (apud AGAMBEN, 2009, p. 58). A contemporaneidade seria uma singular relação com o próprio tempo, que adere a este e, ao mesmo tempo, dele toma distância; mas precisamente, essa é a relação com o tempo que a este adere através de uma dissociação e um anacronismo. A partir dessa fluidez sobre a pertença contemporânea, não precisamos rastrear a data de nascimento do escritor, do filósofo, do artista para que possamos alquimicamente batizá-lo de ser contemporâneo. O mecanismo "batismal" acaba migrando de um espaço temporal (histórico) para um espaço de agenciamento identitário. Para Marc Augé, é preciso que se articulem três perguntas norteadoras: "O que é ser de seu tempo?, O que é nosso tempo hoje?, Onde se situam os pontos de articulação entre nossa época e a criação artística ou literária?" (AUGÉ, 2012, p. 45). Ainda 
é pertinente relembrar o pensamento de Michel Leiris na qual observa que é sempre difícil definir ou localizar os caracteres específicos da época em que se vive. Segundo ambos pensadores, contemporaneidade não é atualidade. Não podemos cair numa inocente equação correlacional na qual existiria uma sinonímia perfeita entre o contemporâneo e o atual. E é justamente aqui que reivindicamos a observação da neurofisiologia da visão como uma possibilidade de identificação da condição contemporânea. O grande desafio está na ausência de balizas paradigmáticas temporais, pois discutir a literatura contemporânea é antes de qualquer coisa perguntar-se quando é o contemporâneo.

E a literatura brasileira contemporânea? Como fica? Qual é a sua cara? Ao longo de eventos e aulas, não são raras as vezes que somos indagados: E aí, professor, qual é a identidade da literatura brasileira contemporânea? É aqui que precisamos arquitetar uma reflexão que não esteja referendada pelos sistemas de semelhança e pela suposta fixidez de uma poética contemporânea. Ao nos depararmos com projetos estéticos tão plurais, evidenciamos quadrantes absolutamente heterogêneos que podem variar de uma palavra-mutilação de Elvira Vigna à palavra-respiração de Almicar Bettega. Assim sendo, talvez tenhamos que responder que a literatura brasileira contemporânea é constelatória. Afinal, uma epistemologia constelatória apresenta-se contra o momento de subjetividade cartesiana, menos preocupada em possuir o fenômeno do que em liberá-lo em seu próprio ser sensível e preservar seus elementos díspares em toda sua irredutível heterogeneidade. A constelação recusa-se a agarrar-se a uma essência metafísica, e articula seus componentes de modo aberto. Como bem ressalta Terry Eagleton, na sua belíssima análise da obra de Walter Benjamin, o conceito de constelação é talvez uma das tentativas modernas "mais originais para romper com versões tradicionais da totalidade, representando uma resistência às formas mais paranoides do pensamento totalizante por pensadores que se opunham a toda simples celebração empirista do fragmento" (EAGLETON, 1993, p. 240). A literatura brasileira contemporânea-constelatória rompe com versões tradicionais de totalidade, pois o continuum letal da história parece abalado pelas lascas e pelos estilhaços de uma estética em constante paralaxe: do intimismo ao realismo, do local ao urbano, do fantástico ao marginal. Se pensarmos a literatura contemporânea como um céu constelado, não apenas marcado por um traço unitário, vislumbraremos uma identificação que não pode ser resumida em poucas particularizações identitárias. Tratemos, então, de praticarmos uma crítica incidental que se permite ao que cai suavemente, como uma folha, sobre o tapete da vida; é aquela dobra leve, fugitiva, no tecido dos dias; é o que mal pode ser anotado: "uma espécie de grau zero da anotação, apenas o necessário para poder escrever alguma coisa" (BARTHES, 2004, p. 47). Segundo Sergio Vaz, "às vezes um poema é o beijo que chega antes da boca" (VAZ, 2012, p. 95). Talvez a literatura contemporânea seja esse beijo que chega antes da boca. Essa boca que é obrigada a enunciar julgamento e valores. Essa boca que é impelida a definir as fronteiras entre a alta literatura e a baixa literatura. Essa boca que é forçada a ter certezas. De qualquer forma, pesquisar o contemporâneo é se aventurar nas estesias provisórias e passageiras. É hesitar sobre o falar e o não falar. É ser beijado por um texto literário mesmo que ainda não seja possível explicá-lo.

\section{Referências}

AGAMBEN, Giorgio. O que é o contemporâneo? E outros ensaios. Chapecó: Argos, 2010.

AUGÉ, Marc. Para onde foi o futuro? Campinas: Papirus, 2012.

BARTHES, Roland. A preparação do romance. São Paulo: Martins Fontes, 2004. v.1.

EAGLETON, Terry. A ideologia da estética. Rio de Janeiro: Jorge Zahar, 1993.

VAZ, Sergio. Literatura, pão e poesia. São Paulo: Global, 2012.

WOOLF, Virginia. O leitor comum. Rio de Janeiro: Graphia, 2007.

\section{Organizador}

(D) RICARDO BARBERENA <ricardo.barberena@pucrs.br>

Pontifícia Universidade Católica do Rio Grande do Sul (PUCRS), Porto Alegre, Rio Grande do Sul, Brasil. 